\title{
RANCANG BANGUN ALAT UKUR TINGGI DAN BERAT BADAN IDEAL BERDASARKAN METODE BROCHA BERBASIS MIKROKONTROLER
}

\author{
Luthfan Maulana ${ }^{1}$, Dodon Yendri ${ }^{2}$ \\ 1,2 Jurusan Sistem Komputer, Fakultas Teknologi Informasi, Universitas Andalas, Padang, 25163
}

\section{ARTICLE INFORMATION}

Received: July 28, 2018

Revised: September 15, 2018

Available online: September 29, 2018

\section{KEYWORDS}

Height, weight, brocha, load cell, ultrasonic

CORRESPONDENCE

E-mail: dodon@ fti.unand.ac.id

\section{A B $\mathbf{S}$ T $\mathbf{R}$ A $\mathbf{C}$ T}

Body's height and mass measurement usually are measured with a different instrument without a knowledge to know the ideal body mass index (BMI). Ideal BMI is related to our health condition especially for people who do exercise. Usually people just guess the BMI from a visual condition that sometime give a false measurement. This paper proposes a device that can measured ideal BMI based on Brocha method based on microcontroller. The body's height will be measured using ultrasonic sensor while the body's mass will be measured with a load cell. The results show that the proposed device can predict the BMI well. The height measurement has a successful rate of $80 \%$.

\section{PENDAHULUAN}

Pada saat sekarang ini teknologi berkembang dengan sangat cepat. Suatu teknologi dapat memiliki satu sampai beberapa fungsi dan kegunaan sekaligus. Dengan perkembangan teknologi, maka teknologi yang diciptakan manusia dapat memberikan banyak kemudahan bagi manusia dalam kehidupan sehariharinya, salah satu contohnya adalah pada bidang kesehatan. Bidang kesehatan seperti rumah sakit telah banyak memanfaatkan kemajuan teknologi untuk membantu pasien dalam pelayanan kesehatan.

Kesehatan merupakan salah satu hal yang sangat penting dalam kehidupan. Manusia yang peduli dengan kesehatannya akan melakukan berbagai cara untuk dapat menerapkan pola hidup yang baik supaya kesehatan tubuh selalu terjaga dan tidak mudah jatuh sakit, dengan memperhitungkan gizi yang cukup dan seimbang sesuai dengan kebutuhan tubuh [1]. Pola hidup sehat juga dapat bermanfaat untuk membentuk berat badan yang ideal yaitu dengan cara menjaga pola makan dan kesimbangan olahraga.

Memiliki badan ideal merupakan keinginan serta dambaan setiap orang baik anak muda maupun orang tua, laki-laki maupun perempuan dengan alasan kesehatan maupun penampilan fisik. Banyak anak muda yang meinginkan dan mendambakan memiliki berat badan yang ideal, dengan alasan memiliki badan yang ideal memberikan dampak terhadap penampilan fisik dan kelihatannya lebih menarik. Banyak cara yang dilakukan anak muda zaman sekarang agar bisa memiliki badan ideal, mulai dari mengatur pola makan, melakukan diet, olahraga dengan teratur hingga meminum obat dan vitamin. Disamping itu saat ini juga banyak dijumpai tempat-tempat kebugaran yang memiliki alat timbangan untuk mengukur berat badan dan alat ukur tinggi berupa mistar tanpa memiliki pengetahuan apakah berat badannya sudah ideal atau belum. Kebanyakan ditempat umum yang menyediakan alat timbangan berat badan masih berupa alat ukur analog biasa dan pengukuran tinggi dengan mistar. Ada juga beberapa tempat yang hanya menyediakan alat ukur berat saja tanpa alat ukur tinggi badan. Oleh karena itu kebanyakan orang hanya mengetahui berat badan nya saja, tanpa mengetahui berapa berat badan ideal yang seharusnya dia capai ataupun untuk mengetahui apakah sudah memiliki badan ideal atau belum[2].

Kebanyakan masyarakat masih banyak yang menerka-nerka apakah badannya sudah ideal atau belum dengan menerka-nerka hanya melihat dengan sebatas pandangan saja untuk menentukan berat badan idealnya. Hal ini disebabkan karena kurangnya informasi untuk mengetahui cara menentukan nilai berat badan yang ideal. Kesulitan dalam menentukan nilai berat badan yang ideal karena tidak mengetahui cara perhitungan rumus dalam mencari nilai berat badan ideal. Oleh karena itu alat ukur tinggi dan berat badan ideal berperan penting sebagai pengukur kondisi kesehatan manusia sesuai dengan kondisi fisik[3]. Penelitian ini melakukan perancangan alat ukur tinggi dan berat badan ideal 
menggunakan metode brocha sebagai perhitungan berat badan ideal, dimana perhitungan tersebut dilakukan berdasarkan jenis kelamin objek sebagai penentu perhitungan berat badan ideal lebih dan efektif. Pemakaian rumus berat badan brocha ini lebih cocok untuk diterapkan pada usia remaja dewasa serta usia dewasa muda.

\section{Perhitungan Berat Badan Ideal Berdasarkan Metode Brocha}

Perhitungan berat badan ideal berdasarkan metode brocha ditemukan oleh Pierre Paul Broca. Dalam mencari nilai pada metode tersebut dibedakan antara jenis kelamin laki-laki dan perempuan. Perbedaan ini disebabkan karena komposisi tubuh laki-laki dan perempuan itu berbeda serta laki-laki lebih memiliki berat otot dan tulang yang lebih besar dibandingkan dengan tubuh perempuan. Disamping itu perempuan lebih banyak memiliki komposisi lemak[4]. Rumus perhitungan brocha pada jenis kelamin laki-laki dapat dilihat pada persamaan 1 dan perempuan pada persamaan 2 berikut.

(TinggiBadan-100) - 10\% x (TinggiBadan-100)) ...... (1)

(TinggiBadan-100) - 15\% x (TinggiBadan-100)) ...... (2)

Dengan ambang batas yang diperbolehkan adalah $\pm 10 \%$ dari berat badan ideal. Apabila hasil perhitungan diperoleh $<90 \%$, maka dikatakan kurus, dan jika $>10 \%$ dikatakan gemuk [5]. Berikut adalah contoh perhitungan nilai brocha berdasarkan jenis kelamin :

\section{Menghitung nilai brocha laki-laki}

Seorang laki-laki memiliki tinggi $175 \mathrm{~cm}$. Berat badan ideal (BBI) dihitung dengan rumus broca persamaan (1) sebagai berikut[6]:

$$
\begin{aligned}
\mathrm{BBI} & =(170-100) \pm(10 \% \times(170-100)) \\
& =70 \pm 7 \\
& =70-7 \text { atau } 70+7 \\
& =63 \text { hingga } 77 \mathrm{~kg} .
\end{aligned}
$$

Jadi berat badan ideal pria dengan tinggi $170 \mathrm{~cm}$ adalah berkisar dari 63 hingga $77 \mathrm{~kg}$.

\section{Menghitung nilai brocha perempuan}

Pada perempuan dengan tinggi badan $150 \mathrm{~cm}$ dan berat badan ideal (BBI) menurut broca persamaan (2) adalah[6]:

$$
\begin{aligned}
\mathrm{BBI} & =(150-100) \pm(15 \% \times(150-100)) \\
& =50 \pm(15 \% \times 50) \\
& =50-7.5 \text { atau } 42.5 \text { atau } 50+7.5 \\
& =42.5 \text { hingga } 57.5
\end{aligned}
$$

Jadi berat badan ideal perempuan dengan tinggi $150 \mathrm{~cm}$ adalah berkisar antara 42.5 dan $57.5 \mathrm{~kg}$.

\section{Sensor Ultrasonik HC-SR04}

Terdapat dua elemen pada sensor ultrasonic HC-SR04 yaitu elemen sebagai pendeteksi dan juga menjadi elemen pembangkit gelombang ultrasonic. Sensor ini dapat mendeteksi gelombang ultrasonic yang mampu mendeteksi gelombang suara dengan frekuensi ultrasonic, yang mana gelombang suara frekuensi diatas kemampuan telinga manusia[7][8].

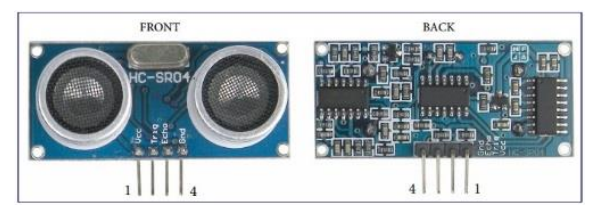

Gambar 1. Sensor Ultrasonik HC-SR04[7]

\section{Sensor Load Cell}

Load cell merupakan komponen utama yang mampu mengubah tekanan yang diberikan beban menjadi sinyal elektrik. Pada pengaturan mekanis dalam bentuk resistor planar, gaya tekan dideteksi berdasarkan deformasi dari matriks pengukur regangan (strain gauges). Regangan mengubah hambatan efektif (effective resistance ) dari 4 pengukur regangan bridge Wheatstone kemudian dibaca berupa perbedaan tegangan[9][10].

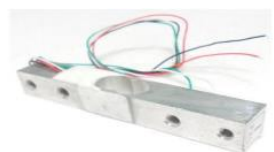

Gambar 2. Sensor Load Cell [9]

\section{Prinsip Kerja Sensor Load Cell}

Saat melakukan penimbangan akan menimbulkan reaksi pada elemen-elemen logam yang terdapat di load cell. Hal ini menimbulkan gaya secara elastis. Gaya yang diperoleh pada regangan, kemudian dikonversikan pada sinyal elektrik oleh pengukur regangan (strain gauge) yang terdapat pada loadc cell. Berikut adalah prinsip kerja load cell berdasarkan rangkaian bridge Wheatstone dapat dilihat pada gambar 3

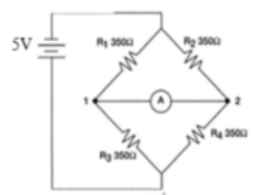

Gambar 3. Rangkaian jembatan Wheatstone tanpa beban

Selanjutnya gambar 4 merupakan rangkaian seimbang, karena nilai $\mathrm{R}=350 \Omega$, pada $\mathrm{R} 1$ dan $\mathrm{R} 3$ besar tegangan mengalir bernilai sama pada R2 dan R4, karena tidak memiliki beda tegangan titik 1 dan titik 2 serta memiliki nilai pada resistor yang sama.

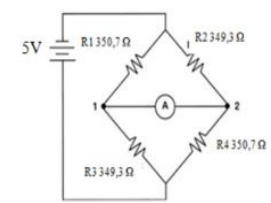

Gambar 4. Rangkaian jembatan Wheatstone dengan beban

Apabila diberi beban, maka nilai $\mathrm{R}$ berubah. Nilai $\mathrm{R} 1=\mathrm{R} 4$ dan R2=R3, akibatnya loadcell tidak dalam kondisi seimbang, maka terjadilah beda potensial yang sebagai ouput[10].

\section{Modul HX711}

HX711 merupakan modul timbangan dengan prinsip kerjanya menguatkan perubahan tegangan yang terukur pada sensor load cell dan mengkonversinya ke dalam besaran listrik melalui rangkaian. HX711 presisi 24-bit analog to digital converter 
(ADC). Data yang dikirim dari load cell yang awalnya berupa sinyal analog menjadi sinyal digital, pada DOUT dan SCK mendapat data dari load cell yang mengubah menjadi sinyal analog menjadi dalam bentuk analog pulsa. Pengambilan data dari modul HX711 menggunakan komunikasi 2 data yaitu data dan clock, disaat data/dout low maka dilakukan pengambilan data ke mikrokontroler sbagai data digital berat yang sudah dikonversi, sebaliknya bila bernilai high maka tidak terjadi pengambilan data[11].

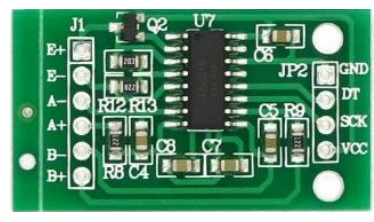

Gambar 5. Modul HX711

Modul HX711 memiliki skala penuh tegangan input diferensial adalah $\pm 40 \mathrm{mV}$, dengan akurasi data 24 bit $\mathrm{A} / \mathrm{D}$ converterChip, memiliki frekuensi refresh $80 \mathrm{~Hz}$, tegangan operasi sebesar $5 \mathrm{~V}$ DC dengan ukuran modul $38 \mathrm{~mm}$ x $21 \mathrm{~mm}$ x $10 \mathrm{~mm}$

\section{DFPlayer Mini}

DFPlayer mini adalah modul mp3 yang outputnya sederhana, dapat langsung diaplikasikan pada pengeras suara speaker. DFPlayer mini dapat digunakan dengan cara berdiri tunggal menggunakan baterai, speaker, dan push button, juga dapat digunakan pada Arduino Uno ataupun dengan perangkat lain yang memiliki kemampuan receiver/transmitter[12].

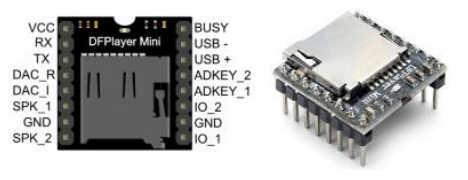

Gambar 6. Modul Mp3 DF Player mini

DF Player Mini mampu menghubungkan modul decoding yang begitu rumit dengn baik, dengan memiliki format audio $\mathrm{mp} 3$, wav, wma, dan juga dapat support TF card dengan sistem file FAT16, FAT32. Melalui port serial sederhana, user bisa memutarkan suara audio yang dipilih tanpa melakukan perintahperintah yang rumit untuk menjalankannya.

\section{Mikrokontroler}

Mikrokontroler adalah sebuah mini processor yang digunakan dalam kepentingan pengontrolan. Mikrokontroler memiliki fisik yang sangat kecil dari pada sebuah personal computer. Mikrokontroler dirancang dengan memiliki elemen dasar yang serupa, walaupun dengan ukurannya yang sangat kecil. Secara umum, terdapat beberapa rangkaian internal pada sebuah microkontroler adalah sebagai berikut: [13]

1. Mikroprosessor: sebuah unit dengan kemampuan evaluasi program dan mengatur jalur data.

2. ROM (Read Only Memory): memori penyimpanan yang bersifat nonvolatile yang artinya mampu menyimpan data didalamya walau tak memiliki sumber tegangan.
3. RAM (Read Acces Memory): memori yang bersifat penyimpanannya secara sementara yang berguna dalam mengeksekusi program.

4. Port I/O: Port Input/Output sebagai port masukan/keluaran microkontroler.

5. Timer: Pewaktu berasal dari ascilator mikrokontroler ataujuga sinyal masukan ke mikrokontroler.

6. EEPROM: Media penyimpan data yang bersifat nonvolatile.

7. ADC: Mengkonversikan sinyal analog berubah jadi data digital.

8. UART: Sebagai interface komunikasi serial asynchronous.

\section{Arduino Uno}

Arduino Uno adalah board mikrokontroler berbasis ATmega328 yang memiliki 14 pin digital input atau output dimana terdapat 6 pin sebagai output PWM, 6 input analog, resonator keramik $16 \mathrm{MHz}$, koneksi USB, jack listrik, header ICSP, dan reset button. Arduino uno dapat menggunakan sumber daya berupa power USB. Apabila dihubungkan dengan komputer menggunakan kabel USB dan bisa juga dengan adaptor atau baterai[14][15].

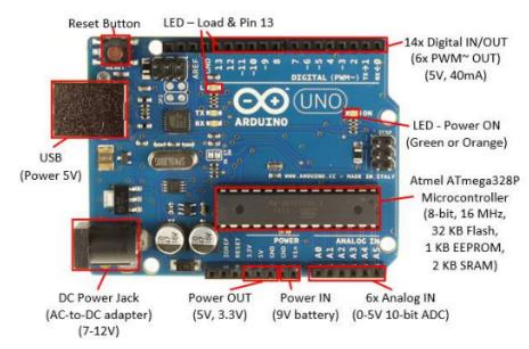

Gambar 7. Arduino Uno

\section{Software Arduino IDE}

Perangkat lunak pada Arduino biasa disebut dengan sketches atau sketsa. Disebut sketsa karena digunakan sebagai media untuk menulis program yang akan ditanamkan pada Arduino. Software arduino uno adalah berupa IDE (Integrated Development Environment) yang dapat dijalankan pada PC. Arduino IDE merupakan sebuah perangkat lunak yang canggih ditulis dengan menggunakan bahasa pemrograman Java[14]. Sebuah arduino IDE terdiri dari:

1. Editor program; sebuah jendela yang digunakan sebagai media yang digunakan oleh sipenggunanya agar dapat menulis program pada bentuk bahasa processing.

2. Compiler; digunakan agar mikrokontroler mampu memahami kode program. Compiler berperan sebagai modul yang mampu mengubah kode program menjadi kode biner, karena sebuah mikrokontroler hanya mampu memahami kode biner agar dapat menjalankan program

3. Uploader; digunakan untuk memuat kode biner dari komputer ke dalam memori didalam board Arduino[14].

\section{Liquid Crystal Display (LCD)}

LCD merupakan media penampil tampilan menggunakn kristal cair selaku penampil utama. Pada umumnya LCD banyak diaplikasikan di berbagai macam bidang seperti layar monitor 
$\mathrm{TV}$, smartphone, kalkulator, ataupun layar monitor komputer. Ada dua buah lembaran bahan pada LCD yang mampu mepolarisasikan kristal cair antara kedua lembaran tersebut. Arus listrik yang melewati cairan menyebabkan kristal merata sehingga cahaya tidak dapat melewati pada setiap kristal, karenanya seperti pengaturan cahaya menentukan apakah cahaya dapat melewati atau tidak. Sehingga bentuk kristal cairannya dapat berubah berbentuk tampilan karakter pada layar[15].

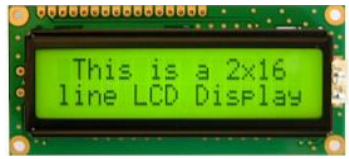

Gambar 8. LCD 16x2[15]

\section{METODOLOGI PENELITIAN}

\section{Perancangan Hardware}

Rancangan hardware pada alat pengukur tinggi dan berat badan ideal ini terdiri dari beberapa komponen seperti sensor load cell, modul hx711, sensor ultrasonik, lcd, dfplayer, pushbutton, speaker dan arduino uno sebagai pusat pengolahan. Semua komponen dapat dilihat pada gambar 9.

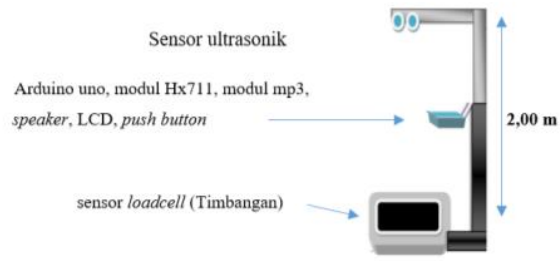

\section{Gambar 9. Rancangan mekanik sistem}

Prinsip kerja dari sistem adalah :

\section{Load cell}

Sensor load cell digunakan sebagai sensor pengukur berat badan. Ketika objek memberi tekanan pada sensor dengan cara berdiri diatas sensor, maka sensor akan mengukur berat objek. Sensor loadcell yang digunakan mampu mengukur berat hingga $200 \mathrm{~kg}$.

\section{Modul HX711}

Sebagai modul timbangan sensor load cell yang digunakan untuk mengubah sinyal analog ke digital agar dapat dibaca oleh program.

\section{Sensor Ultrasonik}

Setelah data berat badan didapatkan maka sensor ultrasonik juga melakukan proses mengukur tinggi badan, dengan cara mengukur jarak yang terbaca pada ultrasonik. Sensor ultrasonik dapat bekerja ketika TX( transmiter ) memancarkan sinyal ultrasonik ke objek lalu mengenai objek, maka sinyal akan dipantulkan oleh objek dan diterima oleh sensor $\mathrm{RX}$ ( receiver ). Data diterima berupa data digital.

\section{Mikrokontroler}

Data tinggi dan berat selanjutnya diproses pada mikrokontroler arduino uno untuk melakukan perhitungan Brocha serta ouput.

\section{LCD}

Hasil perhitungan tinggi dan berat badan ditampilkan pada LCD serta nilai brocha, jenis kelamin dan kondisi tubuh pengguna juga ditampilkan.

6. DF Player Mini (speaker)

Output suara yang didapatkan dari hasil perhitungan brocha berupa saran dalam pembentukan berat badan ideal yang sudah tersimpan pada memori micro SD dikeluarkan melalui speaker

\section{Perancangan Software}

Adapun perancangan software pada sistem ini dapat dilihat pada flowchart gambar 10 berikut ini.

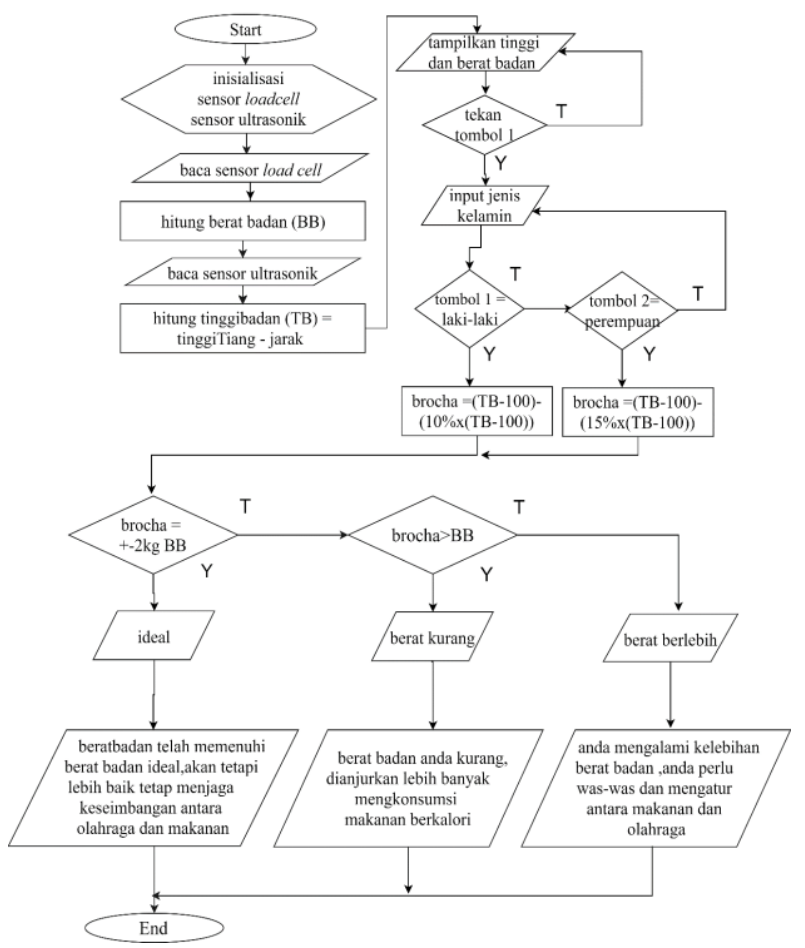

Gambar 10. Flowchart perancangan software

Ketika pengguna atau user berdiri di atas timbangan yang dibawahnya terpasang sensor loadcell dan diatasnya sensor ultrasonik, maka akan diperoleh data tinggi dan berat badan manusia secara otomatis. Data yang diperoleh dari kedua sensor tersebut akan diteruskan ke mikrokontroler untuk dihitung menggunakan rumus brocha. Hasil perhitungan broca akan ditampilkan pada LCD. Selanjutnya user diminta menginputkan jenis kelamin melalui tombol 1 yang gunanya untuk mendapatkan berat badan ideal berdasarkan jenis kelamin menurut metode brocha. Hasil perhitungan berat badan ideal tersebut kemudian ditampilkan pada LCD, dan diteruskan dengan ouput audio sebagai saran dalam pembentukan badan ideal.

Apabila nilai brocha sama dengan berat badan hasil timbangan maka keluaran suara audio berupa 'Berat badan anda normal dan telah memenuhi berat badan ideal akan tetapi lebih baiknya tetap menjaga keseimbangan antara olahraga dan makanan' dan output yang tampil pada LCD adalah 'berat ideal'. Kemudian apabila pada perhitungan hasil brocha lebih kecil dari berat badan hasil timbangan maka komentar dan saran yang akan muncul adalah 'berat badan anda kurang, dianjurkan lebih banyak 
mengkonsumsi makanan berkalori' dan output pada LCD adalah 'berat kurang', dan sebaliknya apabila nilai brocha lebih besar dari berat badan timbangan maka suara yang keluar 'anda mengalami kelebihan berat badan, perlu hatihati dan diatur antara makanan dan olahraga' dan ouput pada LCD adalah 'berat berlebih'.

\section{HASIL DAN PEMBAHASAN}

\section{Implementasi Sistem}

Adapun implementasi sistem perangkat keras pada penelitian ini seperti terlihat pada gambar 11 berikut.

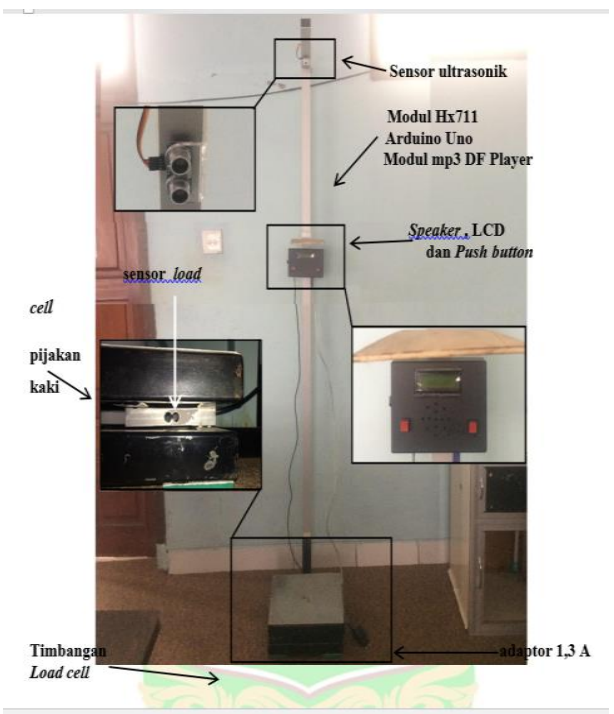

\section{Gambar 11. Alat ukur tinggi dan berat badan ideal}

Keterangan gambar 12:

1. Arduino uno, berfungsi sebagai mikrokontroler untuk memproses seluruh kerja sistem.

2. Sensor ultrasonik, berfungi untuk mengukur tinggi badan user.

3. Load cell, berfungsi untuk menghitung berat badan user.

4. Modul HX711 berfungsi sebagai modul timbangan yang dapat menguatkan perubahan tegangan yang terukur pada sensor load cell dan mengkonversinya kedalam besaran listrik melalui rangkaian.

5. LCD $16 \times 2$, berfungsi sebagai output hasil ukur tinggi dan berat badan serta kondisi badan user yang akan ditampilkan.

6. Modul mp3 DfPlayer mini, berfungsi untuk menyimpan rekaman suara pada memori $S D$ card untuk memancarkan suara melalui speaker.

7. Speaker, berfungsi untuk output suara audio untuk menginputkan jenis kelamin user serta output hasil analisa perhitungan broca dalam pembentukan berat badan ideal.

8. Push button, berfungsi untuk memasuki kondisi dan memilih kondisi.

9. Adaptor 1,3 A berfungsi sebagai sumber daya listrik untuk mnajalankan sistem.

\section{Pengujian Sensor Ultrasonik}

Untuk mendapatkan pengukuran tinggi badan (TB), alat terlebih dahulu dihubungkan ke power supply atau arus listrik. Pada saat sistem telah dihidupkan, pengguna harus berdiri menginjak timbangan loadcell dan berada di bawah sensor ultrasonik dengan menghadap ke tiang atau LCD. Pengguna bisa mengatur posisi papan dengan menaikkan atau menurunkan posisi papan disesuaikan tinggi hingga mendapatkan posisi yang pas. Posisi tubuh harus tegap dan kedua telapak kaki pengguna harus berada diatas timbangan dan berpijak diatasnya dengan kaki sejajar agar mendapatkan pengukuran yang akurat. Posisi dan pengukuran tinggi badan saat penimbangan dapat dilihat pada gambar 12 dibawah ini.

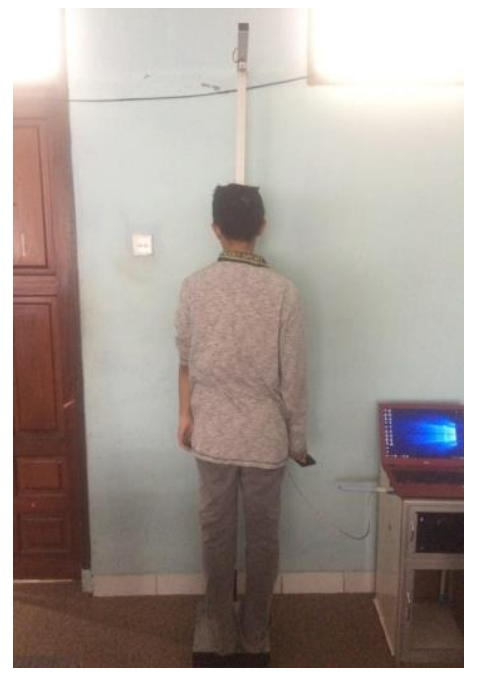

Gambar 12. Posisi Pengukuran tinggi badan

Adapun perbandingan hasil pengukuran tinggi terhadap 10 mahasiswa menggunakan alat yang dibangun dengan manual (mistar) dapat dilihat pada gambar 13 berikut ini.

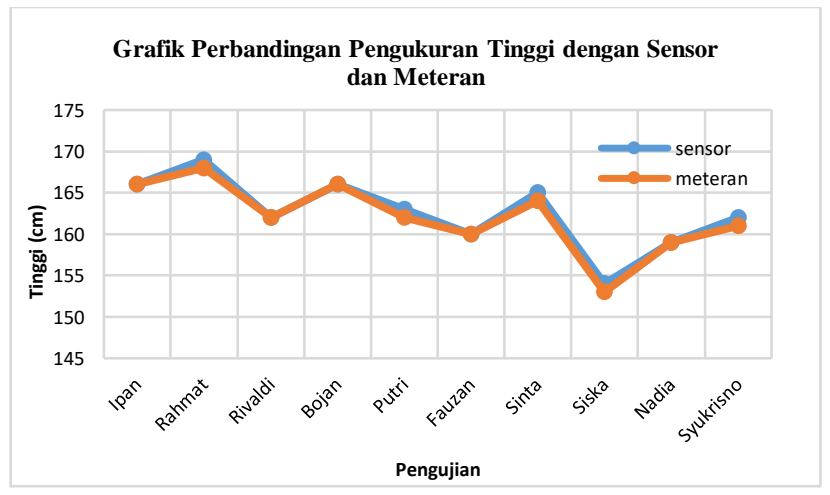

Gambar 13. Grafik perbandingan pengukuran tinggi dengan sensor dan meteran

\section{Pengujian Sensor Load Cell}

Sensor loadcell berfungsi sebagai pendeteksi keberadaan objek dan menghitung massa objek. Sensor load cell yang digunakan dapat menghitung massa maksimal 200kg. Untuk mendapatkan pengukuran berat badan ideal (BBI) yaitu dengan menghubungkan alat tersebut ke power supply atau arus listrik. User berdiri diatas timbangan yang telah dibangun dan menghadap ke tiang atau layar LCD yang sudah dipasang sensor ultrasonik diatasnya. Caranya sama seperti mendapatkan nilai tinggi badan dengan posisi tubuh berdiri tegap dan kedua telapak kaki berada diatas timbangan. Hasil pengukuran berat badan 
menggunakan sensor load cell dapat dilihat juga pada gambar 14 berikut.

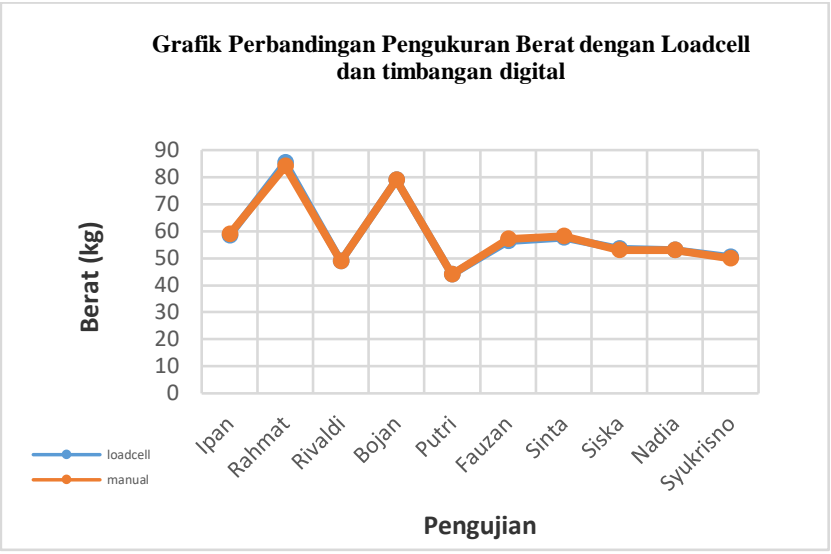

Gambar 14. Perbandingan pengukuran berat dengan loadcell dan timbangan digital

Pembacaan sensor load cell tidak berpengaruh terhadap tekanan posisi pijakan kaki ke alat timbangan. Hasil pengukuran dapat dilihat pada tabel 1 berikut.

Tabel 1. Hasil Uji pembacaan Sensor Load cell berdasarkan posisi kaki berpijak.

\begin{tabular}{|c|c|c|c|c|c|c|}
\hline \multirow[b]{2}{*}{ No. } & \multicolumn{5}{|c|}{ Posisi pijakan kaki diatas timbangan (load cell) } & \multirow{2}{*}{$\begin{array}{l}\% \\
\text { Error }\end{array}$} \\
\hline & $\begin{array}{l}\text { Depan } \\
(\mathrm{kg})\end{array}$ & $\begin{array}{l}\text { Tengah } \\
(\mathrm{kg})\end{array}$ & $\begin{array}{l}\text { Belakang } \\
(\mathrm{kg})\end{array}$ & $\begin{array}{l}\text { Kiri } \\
(\mathrm{kg})\end{array}$ & $\begin{array}{l}\text { Kanan } \\
(\mathrm{kg})\end{array}$ & \\
\hline 1 & 56,35 & 56,35 & 56,35 & 56,35 & 56,35 & 0,00 \\
\hline 2 & 85,26 & 85,26 & 85,26 & 85,26 & 85,26 & 0,00 \\
\hline 3 & 50,04 & 50,04 & 50,04 & 50,04 & 50,04 & 0,00 \\
\hline 4 & 48,83 & 48,83 & 48,83 & 48,83 & 48,83 & 0,00 \\
\hline 5 & 47,21 & 47,21 & 47,21 & 47,21 & 47,21 & 0,00 \\
\hline
\end{tabular}

Berdasarkan pada tabel 1 terdapat 5 macam posisi letak kaki saat berpijak diatas timbangan loadcell yaitu posisi depan, tengah, belakang, kiri, dan, kanan. Setelah dilakukan percobaan sebanyak 5 kali dengan objek yang berbeda tersebut didapatkan nilai berat yang sama walaupun posisi berdiri berbeda-beda dengan persentase error sebesar $0 \%$.

\section{Pengujian Tombol Push Button dan Menampilkan Outputnya pada LCD}

Pertama untuk memasuki perintah input jenis kelamin sekaligus mengambil data tinggi dan berat badan dengan menekan tombol sebelah kiri, jika tidak menekan tombol sebelah kiri maka sistem tidak akan bekerja, apabila sudah menekan tombol sebelah kiri setelah itu masuklah ke perintah inputkan jenis kelamin sekaligus sistem telah mendapatkan data tinggi dan berat badan objek yang tetap, jika objek berjenis kelamin laki- laki tekan tombol sebelah kiri dan jika prempuan tekan tombol sebelah kanan lalu data akan diproses untuk mengetahui hasil perhitungan tinggi dan berat badan ideal serta keluaran suara untuk saran pembentukan badan yang ideal.

Pada penelitian ini terdiri dari 3 input tetapi hanya 2 push button yaitu dengan 1 input digunakan memasuki perintah input jenis kelamin sekaligus menyimpan data tinggi dan berat badan objek dan untuk sensor load cell dan sensor ultrasonik sebanyak 2 input seperti yang terlihat pada gambar 14 dibawah ini :

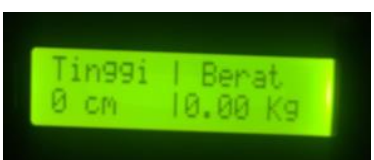

(a)

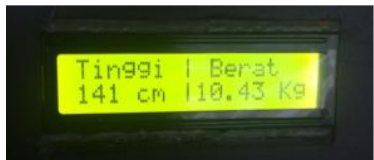

(b)
Gambar 14. Tampilan awal pada LCD

Pada gambar 14(a) merupakan tampilan awal pada LCD ketika alat telah terhubung dengan arus litrik, sedangkan pada gambar 14(b) merupakan tampilan setelah user bediri diatas timbangan alat, maka nilai tinggi dan berat badan langsung ditampilkan pada LCD.

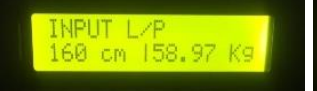

(a)

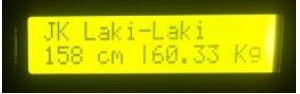

(b)
Gambar 15. Tampilan informasi fisik user pada LCD

Pada gambar 15 merupakan tampilan hasil pengukuran tinggi dan berat badan. Gambar 15(a) merupakan tampilan setelah menekan tombol1 yang berada di sebelah kiri yang berfungsi untuk menyimpan data tinggi dan berat badan sekaligus memasukkan perintah pemilihan jenis kelamin user. Gambar 15(b) adalah tampilan setelah user memilih jenis kelamin dengan menekan tombol1 untuk laki-laki, dan tombol 2 untuk perempuan.

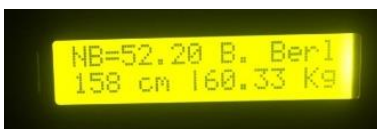

\section{Gambar 16 Tampilan pengukuran berat dan tinggi badan ideal pada LCD}

Gambar 16 merupakan tampilan hasil pengujian pengukuran nilai brocha dengan tulisan $\mathrm{NB}=52,20$, dan menampilkan nilai berat dan tinggi badan ideal setelah memilih kondisi jenis kelamin seperti terlihat pada tabel 2 berikut.

Tabel 2. Hasil uji push button1 dan push button2

\begin{tabular}{|l|l|l|l|l|}
\hline \multirow{2}{*}{ No. } & Jenis kelamin & \multirow{2}{*}{$\begin{array}{l}\text { Push button } \\
\text { perintah INPUT } \\
\text { L/P (tombol1) }\end{array}$} & $\begin{array}{l}\text { Tombol1 } \\
\text { (laki-laki) }\end{array}$ & $\begin{array}{l}\text { Tombol2 } \\
\text { (perempu } \\
\text { an) }\end{array}$ \\
\hline 1. & laki - laki & berfungsi & sesuai & \\
\hline 2. & laki - laki & berfungsi & sesuai & \\
\hline 3. & laki - laki & berfungsi & sesuai & \\
\hline 4. & laki - laki & berfungsi & sesuai & \\
\hline 5. & perempuan & berfungsi & & sesuai \\
\hline 6. & laki - laki & berfungsi & sesuai & \\
\hline 7. & perempuan & berfungsi & & sesuai \\
\hline 8. & perempuan & berfungsi & & sesuai \\
\hline 9. & perempuan & berfungsi & & sesuai \\
\hline 10. & laki - laki & berfungsi & sesuai & \\
\hline
\end{tabular}


Bedasarkan tabel 2 dengan 10 kali pengujian push button bekerja dengan maksimal, tomboll yang berguna untuk perintah INPUT L/P dan tombol1 semuanya berfungsi, dan tomboll untuk jenis kelamin laki-laki dan tombol2 untuk jenis kelamin perempuan juga semuanya sesuai. Hal ini menunjukkan bahwa tingkat pengujian tombol/push button pada semua pengujian bekerja dengan optimal (100\%).

\section{Pengujian Tinggi dan Berat Badan Ideal Berdasarkan Nilai Brocha}

Setelah didapatkan hasil pengujian pengukuran tinggi menggunakan sensor ultrasonik dan berat badan menggunakan sensor load cell yang dikendalikan dengan tombol push buttonl dan pushbutton2, selanjutnya dilakukan pengujian pengukuran menggunakan persamaan (1) dan (2) untuk mendapatkan berat badan ideal (BBI) berdasarkan nilai brocha. Hasil pengujian pada metode brocha akan ditampilkan output-nya di LCD. Tabel 3 memperlihatkan hasil pengujian tinggi dan berat badan metode brocha.

Tabel 3. Pengujian output LCD berdasarkan nilai brocha

\begin{tabular}{|c|c|c|c|c|c|c|}
\hline \multirow[b]{2}{*}{ No } & \multirow{2}{*}{$\begin{array}{l}\text { Jenis } \\
\text { kelamin }\end{array}$} & \multicolumn{2}{|c|}{$\begin{array}{l}\text { Hasil pngukuran } \\
\text { badan }\end{array}$} & \multirow{2}{*}{$\begin{array}{l}\text { Hasil } \\
\text { perhitung } \\
\text { an brocha }\end{array}$} & \multirow{2}{*}{$\begin{array}{l}\text { Tampilan } \\
\text { pada LCD }\end{array}$} & \multirow[b]{2}{*}{$\mathrm{Ket}$} \\
\hline & & $\begin{array}{l}\text { Ting } \\
\text { gi } \\
(\mathrm{cm})\end{array}$ & $\begin{array}{l}\text { Berat } \\
(\mathrm{cm})\end{array}$ & & & \\
\hline 1 & $\begin{array}{l}\text { laki - } \\
\text { laki }\end{array}$ & 166 & 58,51 & ideal & berat ideal & sesuai \\
\hline 2 & $\begin{array}{l}\text { laki- } \\
\text { laki }\end{array}$ & 169 & 85,26 & berlebih & $\begin{array}{l}\text { berat } \\
\text { berlebih }\end{array}$ & sesuai \\
\hline 3 & $\begin{array}{l}\text { laki- } \\
\text { laki }\end{array}$ & 162 & 48,99 & kurang & $\begin{array}{l}\text { berat } \\
\text { kurang }\end{array}$ & sesuai \\
\hline 4 & $\begin{array}{l}\text { laki - } \\
\text { laki }\end{array}$ & 166 & 78,93 & berlebih & $\begin{array}{l}\text { berat } \\
\text { berlebih }\end{array}$ & sesuai \\
\hline 5 & $\begin{array}{l}\text { peremp } \\
\text { uan }\end{array}$ & 163 & 44 & kurang & $\begin{array}{l}\text { berat } \\
\text { kurang }\end{array}$ & sesuai \\
\hline 6 & $\begin{array}{l}\text { laki- } \\
\text { laki }\end{array}$ & 160 & 56,23 & ideal & berat ideal & sesuai \\
\hline 7 & $\begin{array}{l}\text { peremp } \\
\text { uan }\end{array}$ & 165 & 57,61 & ideal & berat ideal & sesuai \\
\hline 8 & $\begin{array}{l}\text { peremp } \\
\text { uan }\end{array}$ & 154 & 53,52 & berlebih & $\begin{array}{l}\text { berat } \\
\text { berlebih }\end{array}$ & $\begin{array}{l}\text { tdk.sesu } \\
\text { ai }\end{array}$ \\
\hline 9 & $\begin{array}{l}\text { peremp } \\
\text { uan }\end{array}$ & 159 & 53,07 & ideal & berat ideal & sesuai \\
\hline 10 & $\begin{array}{l}\text { laki- } \\
\text { laki }\end{array}$ & 162 & 50,15 & ideal & berat ideal & $\begin{array}{c}\text { tdk.sesu } \\
\text { ai }\end{array}$ \\
\hline
\end{tabular}

Dari tabel 3 diatas dapat dilihat bahwa dari 10 kali pengukuran dengan jenis kelamin yang berbeda-berbeda, didapatkan 2 pengujian yang tidak sesuai hasilnya dengan perhitungan nilai brocha, yakni nomor urut 8 jenis kelamin perempuan dengan nilai pembacaan tinggi $154 \mathrm{~cm}$ dan berat 53,52 kg. Hasil perhitungan brocha pada pengujian tersebut 'berlebih' dan seharusnya 'ideal'. Begitu juga pengujian nomor 10 , hasil pembacaan tinggi badan oleh sensor ultrasonik $162 \mathrm{~cm}$ dan berat oleh sensor load cell sebesar 50,15 kg. Hasil perhitungan nilai brocha 'ideal' seharusnya 'kurang'.. Hal ini kemungkinan disebabkan karena pengujian dilakukan pada malam hari dengan pencahayaan yang kurang sehingga pembacaan sensor ultrasonik kurang akurat. Dapat disimpulkan bahwa tingkat keberhasilan perhitungan nilai brocha oleh sistem adalah sebesar $80 \%$.

\section{Pengujian modul mp3 DF Player Mini}

Pengujian modul mp3 DF Player mini, digunakan untuk menyampaikan informasi suara berupa pesan kepada user. Apabila pada gambar 16 tertulis 'B. Ideal' maka modul mp3 akan mengeluarkan suara berupa 'Berat badan anda normal telah memenuhi beratbadan ideal akan tetapi lebih baiknya tetap menjaga keseimbangan antara olahraga dan makanan' sebaliknya apabila tertulis 'B. Kurang' maka modul mp3 akan mengeluarkan suara berupa 'berat badan anda kurang, dianjurkan lebih banyak mengkonsumsi makanan berkalori', dan begitu juga apabila tertulis ' $\mathrm{B}$. Berlebih' maka modul mp3 akan mengeluarkan suara berupa 'anda mengalami kelebihan berat badan, anda perlu was-was dan diatur antara makanan dan olahraga' suara keluar melalui speaker. Tabel 4. memperlihatkan sistem mengeluarkan pesan suara dari sepuluh kali pengujian.

Tabel 4. Pengujian output suara audio berdasarkan nilai brocha

\begin{tabular}{|c|c|c|c|c|}
\hline $\begin{array}{l}\mathrm{N} \\
\mathrm{O} .\end{array}$ & $\begin{array}{l}\text { Jenis } \\
\text { kelam } \\
\text { in }\end{array}$ & $\begin{array}{l}\text { Hasil } \\
\text { perhit } \\
\text { ungan } \\
\text { broch } \\
\text { a }\end{array}$ & $\begin{array}{l}\text { Ouput suara pada audio } \\
\text { (speaker) }\end{array}$ & Ket \\
\hline 1 & $\begin{array}{l}\text { laki - } \\
\text { laki }\end{array}$ & ideal & $\begin{array}{l}\text { Berat badan anda normal } \\
\text { telah memenuhi berat } \\
\text { badan ideal akan tetapi } \\
\text { lebih baiknya tetap } \\
\text { menjaga keseimbangan } \\
\text { antara olah raga dan } \\
\text { makanan }\end{array}$ & sesuai \\
\hline 2 & $\begin{array}{l}\text { laki - } \\
\text { laki }\end{array}$ & $\begin{array}{l}\text { berle } \\
\text { bih }\end{array}$ & $\begin{array}{l}\text { Anda mengalami } \\
\text { kelebihan berat badan, } \\
\text { anda perlu was-was dan } \\
\text { diatur antara makanan } \\
\text { dan olah raga }\end{array}$ & sesuai \\
\hline 3 & $\begin{array}{l}\text { laki - } \\
\text { laki }\end{array}$ & $\begin{array}{l}\text { kuran } \\
\mathrm{g}\end{array}$ & $\begin{array}{l}\text { Berat badan anda kurang, } \\
\text { dianjurkan lebih banyak } \\
\text { memakan makanan yang } \\
\text { berkalori }\end{array}$ & sesuai \\
\hline 4 & $\begin{array}{l}\text { laki - } \\
\text { laki }\end{array}$ & $\begin{array}{l}\text { berle } \\
\text { bih }\end{array}$ & $\begin{array}{l}\text { anda mengalami } \\
\text { kelebihan beratbadan, } \\
\text { anda perlu was-was dan } \\
\text { diatur antara makanan } \\
\text { dan olahraga }\end{array}$ & sesuai \\
\hline
\end{tabular}




\begin{tabular}{|c|c|c|c|c|}
\hline 5 & $\begin{array}{l}\text { pere } \\
\text { mpua } \\
\mathrm{n}\end{array}$ & $\begin{array}{l}\text { kuran } \\
\mathrm{g}\end{array}$ & $\begin{array}{l}\text { beratbadan anda kurang, } \\
\text { dianjurkan lebih banyak } \\
\text { memakan makanan yang } \\
\text { berkalori }\end{array}$ & sesuai \\
\hline 6 & $\begin{array}{l}\text { laki - } \\
\text { laki }\end{array}$ & ideal & $\begin{array}{l}\text { berat badan anda normal } \\
\text { telah memenuhi berat } \\
\text { badan ideal akan tetapi } \\
\text { lebih baiknya tetap } \\
\text { menjaga keseimbangan } \\
\text { antara olah raga dan } \\
\text { makanan }\end{array}$ & sesuai \\
\hline 7 & $\begin{array}{l}\text { pere } \\
\text { mpua } \\
\mathrm{n}\end{array}$ & ideal & $\begin{array}{l}\text { berat badan anda normal } \\
\text { telahmemenuhi } \\
\text { beratbadan ideal } \\
\text { akantetapi lebihbaiknya } \\
\text { tetap menjaga } \\
\text { keseimbangan antara } \\
\text { olahraga dan makanan }\end{array}$ & sesuai \\
\hline 8 & $\begin{array}{l}\text { pere } \\
\text { mpua } \\
\mathrm{n}\end{array}$ & $\begin{array}{l}\text { berle } \\
\text { bih }\end{array}$ & $\begin{array}{l}\text { anda mengalami } \\
\text { kelebihan beratbadan, } \\
\text { anda perlu was-was dan } \\
\text { diatur antara makanan } \\
\text { danolahraga }\end{array}$ & sesuai \\
\hline 9 & $\begin{array}{l}\text { pere } \\
\text { mpua } \\
\mathrm{n}\end{array}$ & ideal & $\begin{array}{l}\text { berat badan anda normal } \\
\text { telah memenuhi berat } \\
\text { badan ideal akan tetapi } \\
\text { lebih baiknya tetap } \\
\text { menjaga keseimbangan } \\
\text { antara olah raga dan } \\
\text { makanan }\end{array}$ & sesuai \\
\hline 10 & $\begin{array}{l}\text { laki - } \\
\text { laki }\end{array}$ & ideal & $\begin{array}{l}\text { berat badan anda normal } \\
\text { telah memenuhi berat } \\
\text { badan ideal akan tetapi } \\
\text { lebih baiknya tetap } \\
\text { menjaga keseimbangan } \\
\text { antara olah raga dan } \\
\text { makanan }\end{array}$ & sesuai \\
\hline
\end{tabular}

Berdasarkan hasil pengujian pada tabel 4 diperoleh bahwa dari 10 kali pengujian semuanya memberikan pesan audio melalui speaker yang sesuai dengan hasil perhitungan nilai brocha. Dengan demikian dapat dikatakan bahwa tingkat keberhasilan modul MP3 DF Player mini memberikan pesan adalah sebesar $100 \%$.

\section{KESIMPULAN}

1. Alat ukur tinggi dan berat badan ideal berdasarkan metode brocha menggunakan sensor ultrasonik untuk mengukur tinggi badan dan sensor load cell untuk mengukur berat badan dapat diimplementasikan dengan baik.

2. Sistem yang dibangun dapat mengukur tinggi dan berat badan ideal menggunakan metode brocha dengan tingkat keberhasilan sebesar $80 \%$.
3. Ouput atau informasi hasil pengukuran tinggi dan berat badan ideal berdasarkan metode brocha dapat ditampilkan pada LCD dan saran dengan suara audio melalui speaker menggunakan modul mp3 DF Player mini dengan tingkat keberhasilan 100\%.

\section{ACKNOWLEDGMENT}

Ucapan terima penulis sampaikan kepada Ipan, Rahmat, Rivaldi, Bojan, Putri, Fauzan, Sinta, Siska, Nadia dan Syukrisno yang telah berkenan membantu penulis untuk melakukan pengujian tinggi dan berat badan untuk mendapatkan berat badan ideal menggunakan metode Brocha.

\section{REFERENCES}

[1] Zakky Aulia, 2015. "Rancang Bangun Alat Pengukur Angka Kecukupan Gizi (AKG) dengan Menggunakan Mikrokontroler". Padang: Tugas akhir sistem komputer. Universitas Andalas

[2] A, Azrul 2010. "Tubuh Sehat Ideal dari Segi Kesehatan".

[3] Thomas, Johan K.W, dan Henhy (2015). "Sistem Pengukur Berat dan Tinggi Badan Menggunakan Mikrokontroler AT89S51”. Jurnal Tesla. 10(2)

[4]https://panduancara.com/cara-menghitung-beratbadan-ideal/ (Diakses pada 16 Desember 2017)

[5] S.Sarwono. 2001. "Pedoman Praktis Memantau Status Gizi Orang Dewasa Untuk Mempertahankan Berat Badan Normal Berdasarkan Indeks Massa Tubuh". Jakarta: Gramedia, ch:2, pp:20-32.

[4] Mega Vitriya, 2015. "Pemindai alat biometrik dengan sensor infrared proximity berbasis mikrokontroler". Padang: Tugas akhir sistem komputer. Universitas Andalas

[5] S.Sarwono. 2001. "Pedoman Praktis Memantau Status Gizi Orang Dewasa Untuk Mempertahankan Berat Badan Normal Berdasarkan Indeks Massa Tubuh”. Jakarta: Gramedia, ch:2, pp:20-32.

[6] https://seimbang.net/cara-menghitung-berat-badanideal/ (Diakses pada 23 November 2017)

[7] Arief, Ulfah Mediaty. 2011."Pengujian Sensor Ultrasonik PING untuk Pengukuran Level Ketinggian dan Volume Air ". Vol 09, No 02. 
[8] Nichols, 1988, "Ultrasonic inspection of heavy section steel". London: Elsevier applied science, ch:3 pp: 81 92.

[9] Purwanto, Dwi. Tanpa Tahun. "Rancang Bangun Load Cell Sebagai Sensor Gaya pada Sistem Uji.Peneliti Balai Besar Teknologi Kekuatan Struktur" -BPPT. 18:3-4.

[10] Rebby Fudi Alexander.2013.“Aplikasi Sensor Berat Load Cell Pada Alat Pengering Herbal"

[11] Dadan Nurdin Bagenda, M.T, Agung Lucky Herdian. Tanpa tahun. Jurnal Tugas akhir dengan judul "Prototipe Jembatan Timbang Menggunakan Bridge Sensor dan Kamera berbasis Mikrokontroler". Program Studi Teknik Informatika STMIK LPKIA.

[12] www.dfrobot.com (Diakses pada 17 Agustus 2017)

[13] Setiawan, Edi. 2009. "Alat Ukur Tinggi Badan Digital Menggunakan Ultrasonik Berbasis Mikrokontroler ATMega16 Dengan Tampilan LCD”. Volume XI, No. 2

[14] Banzi, Massimo. 2008 "Gettting Started with Arduino". O’Reilly.

[15]http://arduino.cc/en/Main/ArduinoBoardUno (Diakses pada 11 Mei 2017)

[16]http://arduino.cc/en/Main/ArduinoBoardUno (Diakses pada 11 Mei 2017)

[17] Setiawan, Edi. 2009. “Alat Ukur Tinggi Badan Digital Menggunakan Ultrasonik Berbasis Mikrokontroler ATMega16 Dengan Tampilan LCD”. Volume XI, No. 2. 